\title{
RELATIONSHIP OF WRITING LEARNING PROCESSES WITH \\ LANGUAGE ERRORS OF STUDENT EXPOSITION (Research Language Errors in SMAN 4 Tambun Selatan)
}

\author{
Ria Anggari Putri \\ Universitas Negeri Jakarta \\ anggari.farried@gmail.com \\ Miftahulkhairah Anwar \\ Universitas Negeri Jakarta \\ miftahulkhairah@unj.ac.id \\ Siti Ansoriyah \\ Universitas Negeri Jakarta \\ siti.ansoriyah@unj.ac.id
}

Accepted: 2020-01-28 , Approved: 2020-01-29 , Published: 2020-01-31

\section{ABSTRACT:}

This study aims to find out and explain the interrelationship of the learning process of writing with errors in the exposition of students. The method used is descriptive qualitative method which aims to describe and explain the relevance of the learning process of writing with the errors of the exposition of students. The object of this research is the exposition of class $X$ high school students assisted by questionnaire. The results of this study indicate that the more maximum the process of learning to write, the better the results obtained, and conversely the instant process and teachers who do not maximize teaching in the methods and media used will be increasingly less quality.

Keywords: writing, language errors, exposition

\section{INTRODUCTION}

Writing is one of the

language skills that must be mastered

by students in the learning process,

writing learning has been instilled

early on from the elementary school

curriculum to high school in every

language learning. One of them is in learning Indonesian. It is said so because learning Indonesian can be used as a means of expressing ideas and self-actualization.

Besides being used as a means of expressing ideas and actualization, writing is also a complex thought process and 
BAHTERA: Jurnal Pendidikan Bahasa dan Sastra, Volume 19 Nomor 1 Januari 2020

http://journal.unj.ac.id/unj/index.php/bahtera/

P-ISSN : 0853-2710

E-ISSN : 2540-8968

requires knowledge, basic skills, strategies, and the ability to coordinate the processes of various parts (Hui, 2015). In addition, writing ability is the most difficult ability to be improved compared to other language skills, such as listening, speaking, and reading (Nada Amelia \& Miftahulkhairah, 2018).

However, in reality in every writing learning especially in Indonesian, there are still many students who make mistakes from their writing or writing activities. In line with the results of an interview with one of the Indonesian language teachers at SMAN 4 Tambun Selatan, it was conveyed that the results of the students' writings were still found to be incomplete with the ideas submitted so it was difficult to understand the ideas or ideas contained in them. Not only that, students also still have difficulty in arranging words and pouring them into writing so that the sentences they make are not coherent. This makes writing made by students difficult to understand for readers (Azzahra, 2017).

In fact, language errors in writing made by students are basically also caused by the teacher himself. Often teachers in teaching do not pay attention to the methods and media used so that students become bored and do not have enthusiasm in learning. Until the material delivered by the teacher was not well received by students, and in the end many language errors were found in students' essays.

Not only that, because the learning process is also less than optimal, so students also have 
BAHTERA: Jurnal Pendidikan Bahasa dan Sastra, Volume 19 Nomor 1 Januari 2020

http://journal.unj.ac.id/unj/index.php/bahtera/

P-ISSN : 0853-2710

E-ISSN : 2540-8968

difficulty in learning and

research from Rustono with the titles

understanding the material delivered

Lexical Cohesion and Grammatical

by the teacher. In addition, students

Cohesion in Scientific Work of

who have difficulty learning on one

Semarang City High School Students

material or subject matter, are also

and published in 2011 (Rustono,

very likely to have difficulty when

2011).

learning the next material. Plus, if

In line with the language

difficulties are not dealt with

immediately, it is feared that students

will continue to experience failure in

learning. The failure will lead to

disappointment, lazy learning, low

self-esteem or may even affect his

soul (I Gst Ayu Winiari \& Negara,

2015). This was also done with

research conducted by Agnes Heppy

Kurniasari with the title Grammatical

and Lexical Cohesion Devices in

Writing Descriptions for Class VIII

Middle School Students and their

Relevance as Indonesian Language

Teaching Materials and published in

2016 (Agnes,2016). Coupled with 
BAHTERA: Jurnal Pendidikan Bahasa dan Sastra, Volume 19 Nomor 1 Januari 2020

http://journal.unj.ac.id/unj/index.php/bahtera/

P-ISSN : 0853-2710

E-ISSN : 2540-8968

language system that they are learning. If the stage of students' understanding of the language system being studied is inadequate then mistakes will often occur and mistakes will be reduced if the stage of student understanding increases (Tarigan, 1988).

Therefore, mistakes made by students in this case need to be done in-depth error analysis, basically the analysis aims to help students understand the material and reduce errors that occur. In this case, language mistakes made by students in the learning process can imply that language teaching goals are still not maximally reached. Especially in the form of essays like exposition essays (Sako, 2017). Expository writing or exposition is a representational writing. As according to (Miftahulkhairah and Sakura
Ridwan, 2012), representational is a conveyor of facts, explain or report an event.

In the learning of composition essay, most of the students' essay found errors related to cohesion. In this case, language errors are not only in speech (spoken language), but also in writing (written language). In written language, the elements of language used must be complete. According to (Sako, 2017) if the elements of the language used are incomplete, the information conveyed also cannot be understood correctly or referred to as written language errors. For this reason, all existing language elements should be used appropriately and effectively and adapted to the purpose, content, and background of the reader. 
BAHTERA: Jurnal Pendidikan Bahasa dan Sastra, Volume 19 Nomor 1 Januari 2020

http://journal.unj.ac.id/unj/index.php/bahtera/

P-ISSN : 0853-2710

E-ISSN : 2540-8968

Related to the cohesiveness

that is contained in student essays mistakes. In this case the structure or organization of discourse is important in discourse analysis which specifically analyzes errors of cohesion (Siti Nur Khafifah, 2016). Actually, in learning to write in school, students often get less attention from the teacher. This is evidenced by the lack of student writing competence in the 2013 curriculum at the high school level. Yet in learning writing has a very many and positive functions for students. The function is to hone the sharpness of thinking and train students' creative thinking. Actually, mistakes in language learning made by students, is not a strange thing because learning and mistakes cannot be separated.
Seeing the importance of

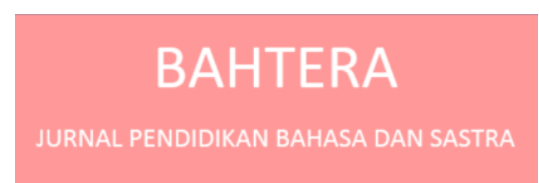

language mistakes with the process of learning to write at school, this study aims to connect and link writing learning processes with writing errors made by students. The subfocus of this research is the relationship between cohesion errors and Indonesian language learning at SMAN 4 Tambun Selatan.

Therefore, to optimize students' writing skills, it is necessary to further investigate the causes and linkages to the learning process itself, so that later teachers and students can work together to realize effective and maximum writing learning.

\section{METHOD}

In general, this study uses a descriptive qualitative method by describing and linking Indonesian learning with exposition essays made 
BAHTERA: Jurnal Pendidikan Bahasa dan Sastra, Volume 19 Nomor 1 Januari 2020

http://journal.unj.ac.id/unj/index.php/bahtera/

P-ISSN : 0853-2710

E-ISSN : 2540-8968

by students. The research was conducted in the even semester of the academic year 2017/2018. The research data is in the form of questionnaires and essays on exposition of class $\mathrm{X}$ students. The form of data obtained in this study is text. These data are obtained from reading carefully and identifying the relationship between the learning and the essay of the students.

\section{RESULTS AND DISCUSSION}

Writing is one of the language skills of Indonesian language subjects at school. Each student is required to take part in learning on writing skills, one of which is writing an exposition essay. The purpose of exposition essay writing skills is so students can develop their ideas into writing.
Moreover, they can train their critical thinking through writing.

Through Indonesian language lessons at school, students are also required to be able to communicate and convey their creative ideas verbally and in writing. Writing is an alternative for students who have many ideas but are not confident to express it directly through oral. Thus, writing an exposition essay becomes one of the skills that must be presented in the process of learning Indonesian.

The writing of the exposition essay was conducted two to three times face to face with each meeting for two hours of study. In the first and second meetings, students understand the concept of exposition essays first. After they learn and understand it, at the next meeting they practice writing in 
BAHTERA: Jurnal Pendidikan Bahasa dan Sastra, Volume 19 Nomor 1 Januari 2020

http://journal.unj.ac.id/unj/index.php/bahtera/

P-ISSN : 0853-2710

E-ISSN : 2540-8968

accordance with the understanding they have received at the previous meeting. In the process of understanding and studying it, they are assisted by the prjector media to display the exposition image and material to make it more interesting and easy to understand. As for the theme used in writing exposition essays is determined by the instructors of each Indonesian language, then students are free to use any title from the theme. Meanwhile, to get data that supports when writing exposition essays, students are allowed to search through other sources such as websites or other supporting sources.

When students write exposition essays, students focus and write ideas into essays, occasionally they look for supporting data through the internet such as trusted websites.
Through the ideas they have, they also compose sentences in order to establish cohesiveness, both lexically and grammatically. Indirectly, students practice their writing skills through cohesion markers that their teacher has taught before. In addition, through writing activities students can establish a form of cooperation between the sensory and motor work methods that are written into writing. Thus, they become trained to develop ideas and make them coherent writing.

Next, when the learning process of writing takes place, many students find it difficult to remember the material, even though the teacher has explained it along with class discussion, but because of the students' limitations in remembering the material so that what the teacher has conveyed is not well absorbed by 
BAHTERA: Jurnal Pendidikan Bahasa dan Sastra, Volume 19 Nomor 1 Januari 2020

http://journal.unj.ac.id/unj/index.php/bahtera/

P-ISSN : 0853-2710

E-ISSN : 2540-8968

students. Difficulty in remembering this material will have an impact when students write exposition essays, because they do not understand how essay writing is cohesive and coherent. Not only that, the methods and media used by the teacher when explaining exposition material also greatly affect students' memory.

Based on the results of the questionnaire, it can be seen that the teacher still does not use learning media which can help students to understand the exposition material so that students become bored when learning takes place and creates many shortcomings in the learning process. The media used when the learning process takes place uses only government textbooks and the blackboard. Very rarely, the teacher displays and explains the material through a projector. Even if the teacher uses more creative media, students become more excited and enthusiastic when learning takes place. Until the results obtained in the learning are maximized, especially the results of the essay exposition. Likewise with themselves, the average is difficult to put ideas into writing, coupled with those who do not have the enthusiasm to ask questions or answer questions from the teacher so that the understanding of their exposition becomes less.

Not only in terms of material, teachers who teach only with the lecture method can be sure students will learn passively and the results are in the form of understanding material is theoretical rather than practical. Therefore, Indonesian language teachers must 
BAHTERA: Jurnal Pendidikan Bahasa dan Sastra, Volume 19 Nomor 1 Januari 2020

http://journal.unj.ac.id/unj/index.php/bahtera/

P-ISSN : 0853-2710

E-ISSN : 2540-8968

know, understand, appreciate, and can practice various language teaching methods (Basuki, 2017)

The teacher is also expected to be able to choose and apply the right teaching methods in each teaching and learning process in the classroom. The method chosen and applied must also be in accordance with the learning objectives, learning materials, and the state of the students such as their abilities, interests, and surrounding environment. The teaching method must also vary and provide a diverse language experience for students, stimulate learning, and facilitate students to understand learning materials. The method chosen must also be easy to operate and does not require complicated tools to use (Basuki, 2017). Besides because of the performance that affects the learning process and the results of students' writing.

Apparently, even in terms of students 'competencies or abilities also influence, including the lack of students' knowledge of the rules in language so that students become confused in applying the correct rules in exposition essays. Because of confusion, students finally generalize the language rules that are being studied so that it causes errors. This can actually also occur because of ignorance of the rules of a language that the teacher could not have explained thoroughly, especially those related to exposition material.

Finally, the cause is due to a misconception. This conceptual error usually occurs because of differences in the language being studied. It could also be due to 
BAHTERA: Jurnal Pendidikan Bahasa dan Sastra, Volume 19 Nomor 1 Januari 2020

http://journal.unj.ac.id/unj/index.php/bahtera/

P-ISSN : 0853-2710

E-ISSN : 2540-8968

differences in capturing the

about exposition is very dependent

explanations of the material

on how the teacher teaches in class.

provided, especially if the student is

In addition, errors that occur in

taking tutoring outside of school,

exposition essay also depend on the

which may have different concepts

competency of the student in

between the school and the tutoring

they are taking.

understanding the material provided

by the teacher at school. Therefore

Thus, the teacher should

we need collaboration between

innovate the language learning

teachers and students in schools to

system, especially in writing

minimize language mistakes

learning, so that the enthusiasm and

passion of the teacher, and students

can grow back so that language

errors, especially in writing can be

minimized.

\section{REFERENCES}

Agnes Heppy Kurniasari, S. C. (2016). Peranti Kohesi Gramatikal dan Leksikal Pada Tulisan Deskripsi Siswa

\section{CONCLUSION}

Kelas VIII SMP dan

From this research illustrates

that the language mistakes made by

students in their essays cannot be separated from the learning process

carried out by teachers at school. The

Relevansinya sebagai Materi

Ajar Bahasa Indonesia .

BASASTRA, 15-16. Volume 4

Nomor 1, April 2016, ISSN

I2302-6405

understanding received by students 
BAHTERA: Jurnal Pendidikan Bahasa dan Sastra, Volume 19 Nomor 1 Januari 2020

http://journal.unj.ac.id/unj/index.php/bahtera/

P-ISSN : 0853-2710

E-ISSN : 2540-8968

Azzahra, F. (2017, Oktober 16).

Karangan Anak di SDN

Wawancara Keterampilan

Jatiwaringin 1 : Suatu Kajian

Menulis Siswa. (Ria,

Berdasarkan Pemerolehan

Interviewer)

Bahasa. Arkhais, 2.

Hui, N. T. (2015). Problems

Siti Nur Khafifah, N. M. (2016).

Affecting Learning Writing

Analisis Kohesi Leksikal

Skill of Grade 11 at Thong

Linh High School. Asian

Journal Of Educational

Research, 53-69.

Terhadap Ungkapan

"Emancipation" Dalam Novel

The Handmaid's Tale Karya

Margaret Atwood. Parafrase,

I Gst Ayu Winiari, I. G., \& Negara, I.

15.

DOI:

G. (2015). Analisis

https://doi.org/10.30996/paraf

Kesulitan-Kesulitan Belajar

$\underline{\text { rase.v16i02.866 }}$

Bahasa Indonesia Kelas V

dalam Implementasi

Kurikulum 2013 di SD

Pilotingse-Kabupaten

Gianyar. Jurnal PGSD, 3.

Miftahulkhairah, S. H. (2012).

Sintaksis. Jakarta: Irham

Publishing.

Rustono, S. W. (2011). Kohesi

Leksikal dan Kohesi

Gramatikal dalam Karya

Ilmiah Siswa SMA Sekota

Semarang. Lingua Jurnal

Bahasa dan Sastra , 42.

Volume VII/1 Januari 2011,

ISSN 1829-9342

Nada Amelia, K., \& Miftahulkhairah.

Sako, Y. (2017). Kesalahan (2018). Afiksasi Pada

Berbahasa Tataran Sintaksis 
BAHTERA: Jurnal Pendidikan Bahasa dan Sastra, Volume 19 Nomor 1 Januari 2020

http://journal.unj.ac.id/unj/index.php/bahtera/

P-ISSN : 0853-2710

E-ISSN : 2540-8968

Pada Penulisan Pengalaman

Pribadi Siswa Kelas X SMA.

Jurnal Pendidikan, 1527.
Tarigan, H. G. (1988). Pengajaran

Analisis

Kesalahan

Berbahasa.

Bandung:

Angkasa Publisher. 